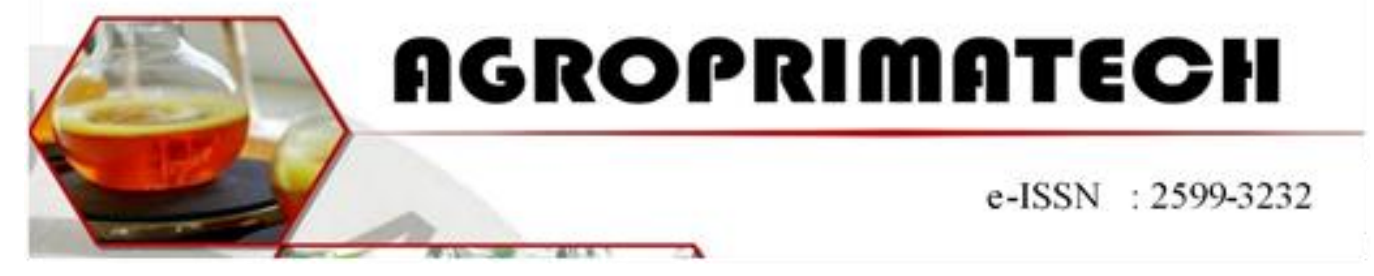

\title{
STANDAR KELAYAKAN PELAYANAN DAN FASILITAS DI TERMINAL PENUMPANG PELABUHAN TANJUNG SAMAK KABUPATEN KEPULAUAN MERANTI
}

\author{
ASADI ${ }^{1}$, TRI MARDALENA², DIKY BUDIMAN³ \\ ${ }^{1}$ Mahasiswa Manajemen Kepelabuhan dan Pelayaran Fakultas Sains dan Teknologi, \\ Universitas Karimun. \\ ${ }^{2,3}$ Dosen Manajemen Kepelabuhan dan Pelayaran Fakultas Sains dan Teknologi, \\ Universitas Karimun \\ Email: dikybudiman@gmail.com
}

\begin{abstract}
ABSTRAK
Pelabuhan juga mempunyai peranan yang sangat penting dalam menunjang kemajuan suatu daerah baik dari segi sosial maupun ekonomi. Penelitian ini untuk mengetahui standar kelayakan pelayanan penumpang di terminal penumpang Pelabuhan Tanjung Samak, Kabupaten Kepualaun Meranti, Provinsi Riau. Penelitian kualitatif. Penelitian Pelayanan dan Fasilitas penumpang Terminal Pelabuhan Tanjung Samak memiliki nilai indeks $29 \%$ dinyatakan Cukup untuk indikator Fasilitas Umum, nilai indeks $35 \%$ dinyatakan Cukup untuk indikator Fasilitas Terminal Penumpang. nilai indeks $20 \%$ dinyatakan Cukup untuk indikator Fasilitas Operasional Penumpang dan nilai indeks $50 \%$ dinyatakan Sedang untuk indikator Fasilitas Penunjang. Berdasarkan Pelayanan dan Fasilitas penumpang Terminal Pelabuhan Tanjung Samak dapat dikatakan belum sesuai standar, hal ini dilihat dari fasilitas yang tersedia dan pelayanan penumpang pengguna jasa yang belum sesuai dengan standar berdasarkan Peraturan Menteri No. 37 Tahun 2015, dimana masih terdapat fasilitas yang tidak ada dan kurang memadai dengan kondisi jumlah penumpang dan kondisi fisik pelabuhan yang mengalami kerusakan.
\end{abstract}

Kata Kunci : Standar, Kelayakan, Pelayanan, Fasilitas, Pelabuhan

\section{PENDAHULUAN}

Pelabuhan merupakan suatu pintu gerbang untuk masuk ke suatu daerah tertentu dan sebagai prasarana penghubung antar daerah, antar pulau, antar provinsi, bahkan antar negara. Pelabuhan juga mempunyai peranan yang sangat penting dalam menunjang kemajuan suatu daerah baik dari segi sosial maupun ekonomi. Peran pelabuhan tersebut hanya dapat dicapai jika pelabuhan tersebut didukung oleh fasilitas yang memadai, sumber daya yang profesional dan sistem manajemen yang baik. Menurut undang-undang No.17 Tahun 2008 tentang pelayaran, "Pelabuhan adalah terdiri dari daratan dan lautan yang memiliki batas-batas tertentu dan sebagai tempat kegiatan pemerintah dan kegiatan pengusaha yang digunakan sebagai tempat bersandar, naik turun penumpang, dan atau tempat bongkar muat barang, berupa terminal dan tempat berlabuh kapal dan memiliki fasiltas keselamatan dan keamanan pelayaran dan kegiatan penunjang dan sebagai tempat perpindahan intra dan antar moda tranpormasi".

Kabupaten Kepulauan Meranti berada di Provinsi Riau dan memiliki 9 Kecamatan, Kecamatan ini terdiri dari, Merbau, Pulau Merbau, Rangsang, 
Rangsang Barat, Rangsang Pesisir, Tasik Putri Puyu, Tebing Tinggi, Tebing Tinggi Barat, Tebing Tinggi Timur. Adapun sembilan kecamatan tersebut mempunyai 6 pelabuhan yang dikenal yaitu Pelabuhan Harapan, Bandul, Melibur, Pelabuhan Selat Panjang, Tanjung Kedabu dan Tanjung Samak. Dari 6 pelabuhan tersebut hanya 2 pelabuhan yang dihampiri oleh kapal ferry yang melayani penumpang ke luar provinsi, yaitu pelabuhan Selat Panjang dan pelabuhan Tanjung Samak, pelabuhan selebihnya hanya beroperasi antar pulau. Tanjung Samak merupakan Desa yang berada di Kecamatan Rangsang Kabupaten Kepulauan Meranti memiliki sebuah pelabuhan yang menjadi pintu gerbang utama ke pulau Rangsang melalui transportasi air yaitu pelabuhan lalu lintas laut yang bernama pelabuhan Tanjung Samak. Terminal penumpang Pelabuhan Tanjung Samak hanya melayani pelayaran domestik bertujuan ke Tanjung Batu, Tanjung Balai Karimun, Batam, Selat Panjang, Bengkalis, Buton, Pulau Topang, dan Teluk Buntal.

Pelabuhan Tanjung Samak belum memiliki jalur ke luar negeri, sehinggga diharuskan masyarakat setempat untuk menyeberang ke Tanjung Balai Karimun untuk menuju ke luar negeri sepeti Malaysia dan Singapura, 60\% masyarakat Pulau Rangsang bekerja di Malaysia, hal inilah yang menyebabkan jadwal keberangkatan dari Tanjung Samak menuju tanjung Balai Karimun untuk pergi ke Malaysia tidak pernah sepi. Kondisi fasilitas terminal penumpang di Pelabuhan Tanjung Samak Kabupaten Kepulauan Meranti saat ini belum memadai, karena tidak terdapatnya terminal kedatangan dan keberangkatan untuk penumpang kapal pelayaran domestik sehingga tidak memiliki sirkulasi yang jelas antara kedatangan dan keberangkatan penumpang kapal. Fasilitas kursi ruang tunggu yang tidak memadai, dan tidak ada wc atau toilet yang disediakan untuk umum.

Ada beberapa pelayanan terminal penumpang dipelabuhan Tanjung Samak belum memenuhi kriteria antara lain: fasilitas pelayanan yang kurang memadai diakrenakan terdapat kerusakan pada dermaga yang saat ini dalam perbaikan jkarena ambruk, layanan keselamatan belum memenuhi kreteria diantaranya belum ada nomor telpon darurat, perlengkapan P3K (Pertolongan Pertama pada Kecelakaan). Layanan keamanan dan ketertiban, terminal penumpang Tanjung Samak sudah tersedia tangga untuk naik turun dari dan ke kapal yang tidak dilengkapi dengan atap, tersedia pos penjagaan yang kurang terawatt fasilitas kantornya. Layanan kehandalan dan keteraturan terminal penumpang Tanjung Samak belum tersedia informasi jadwal keberangkatan dan kedatangan kapal pada pelabuhan setempat. Layanan kenyamanan terminal penumpang Tanjung Samak belum cukup tersedia yaitu toilet dan musholla. Layanan kemudahan terminal penumpang Tanjung Samak belum dilengkapi untuk informasi dalam bentuk audio. Layanan kesetaraan terminal penumpang Tanjung Samak belum tersedia fasilitas yang disediakan untuk penumpang difable.

Pelabuhan Tanjung Samak merupakan salah satu roda perekomian daerah Kabupaten Meranti dan sekitarnya. Sehingga untuk mempermudah pelayanan terhadap publik pihak pengelola harus memberikan pelayanan yang terbaik dan memberikan fasilitas penunjang yang memadai. Dikarenakan dalam mendekati hari lebaran maupun hari libur panjang calon penumpang kapal mengalami peningkatan yang signifikan sehingga pengelola perlu mengantisipasinya dengan baik, dengan memprioritaskan pelayanan yang baik, fasilitas yang memawadai serta kenyamanan dan keamanan penumpang kapal. Sedangkan terminal penumpang pelabuhan Tanjung Samak merupakan fasilitator semua kegiatan yang terjadi di pelabuhan yang melayani keberangkatan maupun kedatangan penumpang kapal laut domestik, dengan memberikan fasilitas yang memadahi terhadap calon penumpang dan pengunjung terminal pelabuhan. Lokasi pelabuhan Tanjung Samak yang berada di daerah ramai, merupakan tempat yang memiliki potensi yang cukup bagus dalam bidang infranstruktur dan terjangkau dari 
berbagai daerah Kabupaten Merati dan sekitarnya. Hal ini lah yang mendorong peneliti untuk melakukan penelitian di pelabuhan Tanjung Samak untuk mengetahui fasilitas dan standar kelayakan dengan judul "Standar kelayakan pelayanan dan fasilitas di terminal penumpang pelabuhan Tanjung Samak kabupaten Kepulauan Meranti”.

\section{METODE PENELITIAN}

Sampel dalam penelitian ini diambil dengan teknik purposive sampling. Sampel pada penelitian ini berjumlah 24 responden angket dan 2 orang untuk menjawab wawancara tertutup yaitu pegawai Dinas Perhubungan pada Pelabuhan Tanjung Samak. Penelitian ini menggunakan pendekatan deskriptif. Penelitian ini akan dilakukan pada bulan Agustus 2019 sampai Bulan Desember 2019.Analisis data penelitian kualitatif menurut Miles dan Hubermen ada tiga tahap, yaitu tahap reduksi data, tahap penyajian, dan tahap penarikan kesimpulan dan verifikasi data.Pada penelitian ini peneliti menggunakan 3 instrumen penelitian, diantaranya: observasi, wawancara, dokumentasi dan kuesioner.

\section{HASIL DAN PEMBAHASAN}

\section{Analisa Pelabuhan Tanjung Samak Berdasarkan Peraturan Menteri No. 37 Tahun 2015 ;}

Sebagai Pelabuhan yang aktif, Pelabuhan Tanjung Samak tidak dilengkapi dengan infrastruktur yang memadai dalam menjalakan fungsinya. Adapun fasilitas Pelabuhan saat ini yaitu, pintu gerbang Pelabuhan, pos jaga, lapangan Tabel 45 Fasilitas penumpang terhadap Kondisi Pelabuhan Tanjung Peraturan Menteri No. 37 Tahun 2015

\begin{tabular}{|l|l|l|}
\hline $\begin{array}{l}\text { Jenis Pelayanan } \\
\text { Berdasarkan Standar Pelayanan }\end{array}$ & $\begin{array}{l}\text { Kondisi } \\
\text { Pelabuhan } \\
\text { Tanjung } \\
\text { Samak }\end{array}$ & Keterangan \\
\hline $\begin{array}{l}\text { 1. Fasilitas umum } \\
\text { 1) Fasilitas pada zona pertemuan laut }\end{array}$ & $\checkmark$ & \\
\hline
\end{tabular}

penumpukan, perkantoran, loket tiket, gudang, dan dermaga. Masih minimnya sarana penunjang di Pelabuhan Tanjung Samak, tidak mengoptimalkan para penumpang atau pengguna dalam segi fasilitas. Para calon penumpang kesulitan mencari tempat istrahat saat menunggu ferry yang akan berangkat, tidak adanya tempat atau fasilitas dalam menunjang penumpang yang datang maupun tiba di pelabuhan Tanjung Samak saat ini sangat menyulitkan penumpang dan tidak terkoordinirnya para penumpang.

Pada bab ini akan diuraikan mengenai fasilitas Pelabuhan Tanjung Samak terhadap Standar Pelayanan fasilitas pelabuhan berdasarkan Peraturan Menteri No. 37 Tahun 2015 pasal 2 ayat (2) huruf a. Dari hasil penelitian terhadap Standar yang berdasarkan kebijakan dapat diaktakan bahwa fasilitas yang dimiliki Pelabuhan Tanjung Samak belum dikatakan SESUAI karena kondisi pelabuhan masih banyak yang harus dilengkapi baik dari segi pelayanan maupun fasilitas yang tersedia. Hal ini dapat dilihat masih etrdapat kurangnya fasiliats pelayanan, yaitu tidak terdapat kantor agen tiket, ruang tunggu yang belum memadai, kondisi dermaga yang mengalami kerusakan dan sampai saat ini belum diperbaiki, fasilitas turun naik penumpang yang kurang baik karena dapat mengakibatkan kecelakaan pada penumpang dan ruang parkir yang belum tertata baik, sehingga banyak penumpang menurunkan barang dan orang di tempat yang tidak sesuai aturan, terkadang di badan jalan sehingga terjadi kemacetan. Untuk lebih jelas mengenai kondisi Pelabuhan Tanjung Samak berdasarkan Peraturan Menteri No. 37 Tahun 2015, sebagai berikut: i Pelabuhan Tanjung Samak berdasarkan

1) Fasilitas pada zona pertemuan laut 


\begin{tabular}{|c|c|c|c|}
\hline $\begin{array}{l}\text { 2) } \\
\text { 3) }\end{array}$ & $\begin{array}{l}\text { Fasilitas yang menghubungkan dengan } \\
\text { operasional kapal, seperti ponton dan } \\
\text { alat penambat. } \\
\text { Fasilitas yang menghubungkan dengan } \\
\text { perpindahan penumpang, seperti } \\
\text { jembatan dan selasar penghubung. }\end{array}$ & $\checkmark$ & $\begin{array}{l}\text { Masih } \\
\text { sederhana } \\
\text { dan tidak } \\
\text { sesuai } \\
\text { standar }\end{array}$ \\
\hline $\begin{array}{l}\text { 2. Fas } \\
\text { 1) }\end{array}$ & $\begin{array}{l}\text { litas pada zona proses } \\
\text { Fasilitas terminal penumpang. } \\
\text { a) Pelayanan pra dan purna perjalanan } \\
\text { penumpang. } \\
\text { b) Pelayanan informasi dan penjualan } \\
\text { tiket. } \\
\text { c) Pelayanan proses perpindahan } \\
\text { penumpang dan barang. } \\
\text { d) Pelayanan penunjang untuk } \\
\text { memenuhi kebutuhan penumpang. } \\
\text { e) Pelayanan pengawasan } \\
\text { penumpang. }\end{array}$ & $\begin{array}{l} \\
- \\
- \\
- \\
- \\
-\end{array}$ & $\begin{array}{l}\text { Belum sesuai } \\
\text { standar } \\
\text { pelabuhan }\end{array}$ \\
\hline $\begin{array}{l}\text { 3. Fas } \\
\text { 1) }\end{array}$ & $\begin{array}{l}\text { litas operasional penumpang } \\
\text { Fasilitas pada zona pertemuan darat. } \\
\text { a) Fasilitas parkir, } \\
\text { b) Pelantar naik turunnya penumpang, } \\
\text { c) Fasilitas pejalan kaki, } \\
\text { d) Fasilitas jalan masuk kendaraan. }\end{array}$ & $\begin{array}{l}\checkmark \\
\checkmark\end{array}$ & $\begin{array}{l}\text { Belum } \\
\text { tertata baik }\end{array}$ \\
\hline $\begin{array}{l}\text { 2. Fas } \\
\text { a) } \\
\text { b) } \\
\text { c) }\end{array}$ & $\begin{array}{l}\text { ilitas penunjang } \\
\text { Fasilitas komersial, } \\
\text { Fasilitas perkantoran } \\
\text { Fasilitas rekreasi }\end{array}$ & $\begin{array}{l}\checkmark \\
\checkmark\end{array}$ & $\begin{array}{l}\text { Perlu banyak } \\
\text { perbaikan }\end{array}$ \\
\hline
\end{tabular}

Sumber: Peraturan Menteri No. 37 Tahun 2015

Penjelasan:

Standar fasilitas penumpang di terminal penumpang Pelabuhan Tanjung Samak, Kabupaten Kepualaun Meranti, Provinsi Riau.

a. Fasilitas Umum

1) Fasilitas pada Zona pertemuan laut

Terminal penumpang kapal laut adalah komponen penting dalam sistem transportasi laut yang berfungsi sebagai daerah pertermuan antara transportasi laut dan darat serta merupakan tempat perpindahan penumpang, baik dari tranportasi laut sejenis, maupun perpindahan ke transportasi darat atau sebaliknya. Terminal juga merupakan bagian dari pelabuhan yang di bangun sebagai zona transisi dari daerah laut ke darat dan dari penggunaan transportasi laut ke transportasi darat yang berfungsi sebagai wadah pelayanan penumpang dan barang, dimana terjadinya kegiatan transit, embarkasi, dan debarkasi.

a) Fasilitas yang menghubungkan dengan operasional kapal seperti ponton dan alat tambat

Ponton merupakan suatu jenis kapal yang dengan lambung datar atau suatu kotak besar yang mengapung, digunakan untuk mengangkut barang dan ditarik dengan kapal tunda atau digunakan untuk mengakomodasi pasang-surut seperti pada dermaga apung. Dalam penelitian ini ponton mengalami kerusakan dikarenakan 
gelombang dan angina kencang. Sehingga penumpang kesulitan dalam naik dan turun kapal. Belum juga digantinya tiang dolphin pelabuhan tersebut menyebabkan sejumlah kapal ferry tidak bersandar di ponton. Kapal ferry menggunakan badan dermaga (trestel) untuk menurunkan dan menaikkan penumpang meskipun membahayakan penumpang. Tiang Dolphin Pelabuhan Tanjung Samak baru dipesan, Kapal Ferry Belum bisa bersandar di Ponton.

b) Fasilitas yang menghubungkan dengan perpindahan penumpang seperti jembatan dan selasar penghubung.

Dalam penelitian ini, jembatan merupakan suatu penghubung dari suatu tempat ke tempat yang lain yang terpisahkan oleh laut atau yang lainnya. Berdasarkan observasi kondisi jembatan naik turun penumpnag pada pelabuhan tanjung smak sangat sederhana yang terbuat dari kayu dikarenakan ambuknya ponton.

\section{2) Fasilitas pada zona proses}

Pada uraian ini terdiri dari; Pelayanan informasi dan penjualan tiket, Pelayanan proses perpindahan penumpang dan barang, Pelayanan penunjang untuk memenuhi kebutuhan penumpang, Pelayanan pengawasan penumpang dan Fasilitas operasional penumpang terminal, biasanya terdiri atas fasilitas-fasilitas bagi perusahaan pelayaran belum ada. Dari hasil observasi ditemykan bahwa untuk penjualan tiket, agen terletak diluar pelabuhan Tanjung Samak sehingga para agen penjual tiket hanya berdiri di pelabuhan.

\section{3) Fasilitas pada zona pertemuan darat}

a) Fasilitas parkir

Fasilitas Parkir adalah lokasi yang ditentukan sebagai tempat pemberhentian kendaraan yang tidak bersifat sementara untuk melakukan kegiatan pada suatu kurun waktu. Pada pelabuhan Tanjung Samak kondisi parkir seluas 2 meter dan jika parkir penuh, maka kendaraan diparkirkan disepanjang jalan, hal ini dapat mengganggu ketertiban lalu lintas kendaraan. Kurang areal perparkiran ini menyebabkan kendaraan pada badan jalan tidak teratur dan terjadi kemacetan.

Meningkatnya tingkat perjalanan maka meningkat pula kebutuhan ruang parkir yang dibutuhkan dengan kekhawatiran ini juga semakin meningkat. Dengan permasalahan ini maka dibutuhkan kualitas parkir yang baik dan lahan yang mampu menampung semua kendaraan. Selain itu meningkatnya kepemilikan sebuah kendaraan juga memicu peningkatan kapasitas parkir. Kegiatan parkir adalah kecenderungan pengguna kendaraan untuk melakukan perparkiran dan dapat dibagi menjadi dua yaitu: Kegiatan parkir tetap dan kegiatan parkir yang sementara. Dari hasil observasi didapati bahwa parkir di pelabuhan terdiri dari dua macam yaitu pekerja dan pengunjung. Pekerja umumnya parkir untuk jangka panjang dan untuk parkir pengunjung untuk jangka pendek. Dan kegiatan parkir yang sementara yaitu dimana durasi parkir berkisar antara setengah jam sehingga waktu keluar yang bersamaan membuat pintu keluar dan jalan keluar harus cukup besar atau lebih dari satu sehingga memudahkan pengunjung untuk keluar.
b) Pelantar
naik penumpang

Selama ini, aktivitas kapal penumpang di Pelabuhan Tanjung Samak hanya memiliki pelantar kayu. Kondisi pelantar yang rusak, dan tidak nyaman lagi. Yang perlu diperhatikan, adalah keselamatan penumpang. Pemilik kapal atau tidak perlu khawatir menggunakan pelabuhan Tanjung Samak, sebab, tidak dipungut bayaran.

\section{4) Fasilitas pejalan kaki dan masuknya kendaraan}

Fasilitas pejalan kaki adalah istilah dalam transportasi yang digunakan untuk menjelaskan orang yang berjalan di lintasan pejalan kaki baik dipinggir jalan, trotoar, lintasan khusus bagi pejalan kaki ataupun menyeberang jalan.

Dari hasil penelitian fasilitas pejalan kaki belum dikatakan baik, karena belum teratur. Dapat terlihat antara kendaraan dan pejalan kaki mausk dalam satu jalur jalan yang sama. Hal ini juga bisa mengakibatkan 
kemacetan bila disaat ramainya penumpang dihari libur dan hari besar.

\section{b. Fasilitas penunjang}

\section{1) Fasilitas Perkantoran}

Fasilitas kantor adalah sarana pendukung dalam aktivitas perusahaan berbentuk fisik, dan digunakan dalam kegiatan normal perusahaan, memiliki jangka waktu kegunaan yang relatif permanen, dan memberikan manfaat untuk masa yang akan datang. Karakteristik fasilitas kantor yang mencakup sarana dan prasarana pendukung dalam proses aktivitas perusahaan/organisasi antara lain sebagai berikut:

a. Mempunyai bentuk fisik

b. Memberikan manfaat dimasa yang akan datang

\section{2) Fasilitas Komersial}

Fasilitas Komersial adalah bangunan yang digunakan untuk kegiatan jual beli terhadap suatu produk/jasa ataupun objek yang didalamnya terdapat aktifitas ekonomi. Dari hasil penelitian yang dilakukan akwasan Tabel 4.6 Tanggapan Responden

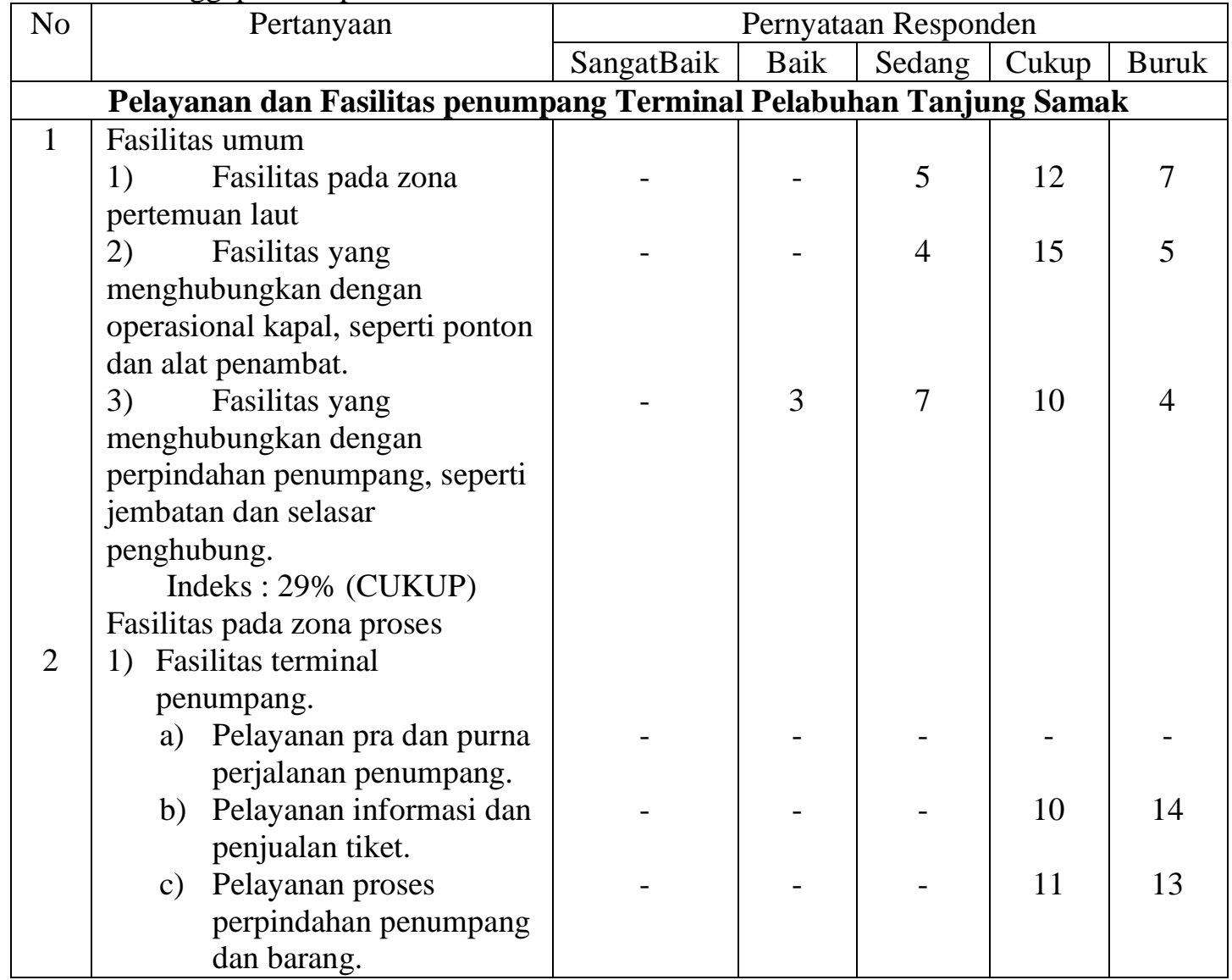

komersial yang etrdapat pada Pelabuhan Tanjung Samak etrdiri dari rumah makan yang terletak disepanjang jalan masuk menuju Pelabuhan. Disamping rumah makan tersebut terdapat warung kecil. Tempat berjualan rokok, permen dan berbagai macam kebutuhan yang lain.

\section{Analisa \\ Berdasarkan Tanggapan} Responden : Hasil penelitian ini di analisis secara deskriptif. Analisis deskriptif dilakukan dengan cara mendeskripsikan setiap butir pertanyaan, yang bertujuan untuk memperoleh gambaran mengenai variablevariabel yang diteliti. Sampel yang diuji adalah responden pada pelabuhan Tanjung Samak yang berjumlah sebanyak 24 orang. Dalam mengukur tanggapan responden terhadap pelayanan dan fasilitas di terminal penumpang pelabuhan Tanjung Samak Kabupaten Kepulauan Meranti. Tanggapan pernyataan responden terhadap kuesioner dan hasil wawancara dapat dilihat pada tabel di bawah ini; 


\begin{tabular}{|c|c|c|c|c|c|c|}
\hline . & 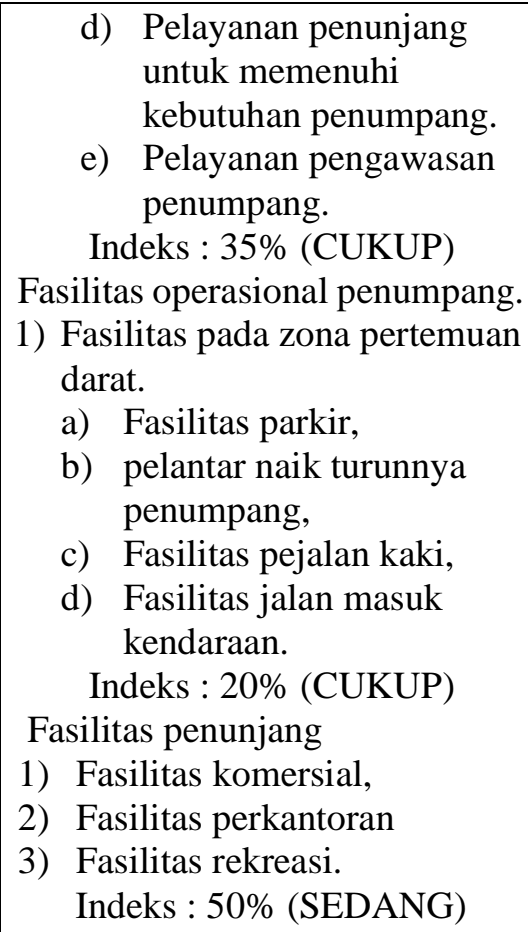 & $\begin{array}{l}- \\
- \\
-\end{array}$ & $\begin{array}{l}- \\
-\end{array}$ & $\begin{array}{c}15 \\
17 \\
-\end{array}$ & $\begin{array}{l}12 \\
14\end{array}$ & $\begin{array}{l}- \\
- \\
-\end{array}$ \\
\hline
\end{tabular}

Sumber : Data olahan, 2019

Untuk lebih jelasnya hasil tanggapan responden dan hasil analisa wawancara dapat dilihat pada tabel berikut ini:

Tabel 4.7 Hasil Tanggapan Deskriptif

\begin{tabular}{|c|l|c|c|l|}
\hline No & Indikator & Indeks & Interpretasi & \multicolumn{1}{|c|}{ Hasil Wawancara } \\
\hline 1 & Fasilitas & $29 \%$ & Cukup & $\begin{array}{l}\text { Hal ini dapat dilihat bahwa fasilitas yang } \\
\text { menghubungkan dengan operasional kapal, } \\
\text { seperti ponton dan alat penambat masih } \\
\text { dalam perbaikan dikarenakan ponton } \\
\text { mengalami kerusakan diakibatkan cuaca } \\
\text { buruk sehingga menganggu kenyamanan } \\
\text { penumpang dalam melakukan } \\
\text { keberangkatan. Selain itu, fasilitas yang } \\
\text { menghubungkan dengan perpindahan } \\
\text { penumpang, seperti jembatan dan selasar } \\
\text { penghubung. Juga dalam keadaan kurang } \\
\text { baik yaitu berupa papan kecil untuk melintas } \\
\text { dari kapal ke pelabuhan sehingga } \\
\text { membahayakan penumpang. (Sumber } \\
\text { Nurmuddin Ketua UPTD) }\end{array}$ \\
\hline 2 & $\begin{array}{l}\text { Fasilitas } \\
\text { Terminal } \\
\text { Penumpang }\end{array}$ & $35 \%$ & Cukup & $\begin{array}{l}\text { Hal ini dapat dilihat bahwa Pelayanan pra } \\
\text { dan purna perjalanan penumpang belum ada. } \\
\text { Pelayanan informasi dan penjualan tiket } \\
\text { sudah ada tapi belum memiliki agen tiket } \\
\text { yang menetap pada pelabuhan. Pelayanan } \\
\text { proses perpindahan penumpang dan barang } \\
\text { kurang memadai dikarenakan belum } \\
\text { memiliki tempat penampung barang bawaan }\end{array}$ \\
\end{tabular}




\begin{tabular}{|c|c|c|c|c|}
\hline & & & & $\begin{array}{l}\text { penumpang. Pelayanan penunjang untuk } \\
\text { memenuhi kebutuhan penumpang belum } \\
\text { memadai tapi sudah bisa digunakan untuk } \\
\text { lancarnya aktivitas kepelabuhanan. Dan } \\
\text { Pelayanan pengawasan penumpang sudah } \\
\text { ada di tangani oleh Dinas Perhubungan, } \\
\text { Syahbandar dan Polisi Pelabuhan. (Sumber: } \\
\text { Nurmuddin Ketua UPTD) }\end{array}$ \\
\hline 3 & $\begin{array}{l}\text { Fasilitas } \\
\text { Operasional } \\
\text { Penumpang }\end{array}$ & $20 \%$ & Cukup & $\begin{array}{l}\text { Hal ini dapat dilihat bahwa fasilitas pada } \\
\text { parkir belum terkoordinasi dengan baik } \\
\text { dimana penumpang dan pengantar } \\
\text { meletakkan kendaraannya dan menurunkan } \\
\text { penumoang pada badan jalan sehingga } \\
\text { kurang tertib. Pelantar naik turunnya } \\
\text { penumpang masih berupa papan } \\
\text { penyeberangan kecil sehingga } \\
\text { membahayakan penumpang. Fasilitas } \\
\text { pejalan kaki belum tertib karena masih } \\
\text { bercampur dengan jenis kendaraan. Dan } \\
\text { fasilitas jalan masuk kendaraan sudah ada. } \\
\text { (Sumber: Beni Riansyah Bagian Lapangan) }\end{array}$ \\
\hline 4 & $\begin{array}{l}\text { Fasilitas } \\
\text { Penunjang }\end{array}$ & $50 \%$ & Sedang & $\begin{array}{l}\text { Hal ini dapat dilihat bahwa Fasilitas } \\
\text { Penunjang yang tersedia yaitu fasilitas } \\
\text { komersial dan fasilitas perkantoran. Fasilitas } \\
\text { komersial berupa rumah makan sudah } \\
\text { tersedia tapi masih bangunan baru yang } \\
\text { terdapat dipinggir pelabuhan dan warung } \\
\text { kecil, dan untuk fasilitas Kantor terdapat } 2 \\
\text { Kantor Dishub dan Kantor Syahbandar yang } \\
\text { melakukan pengawasan pada pelabuhan. } \\
\text { (Sumber : Beni Riansyah Bagian Lapangan) }\end{array}$ \\
\hline
\end{tabular}

Sumber : Data Primer, 2019

\section{PEMBAHASAN}

Berdasakan hasil penelitian ini menunjukkan bahwa tingkat pelayanan dan fasilitas penumpang Terminal Pelabuhan Tanjung Samak adalah CUKUP. Berdasarkan hasil perhitungan sebelumnya didapatkan hasil bahwa indeks tentang Pelayanan dan Fasilitas penumpang Terminal Pelabuhan Tanjung Samak didapati nilai indeks berkisar dari $29 \%-50 \%$ yang memiliki pernyataan kategori CUKUP. Hal tersebut menandakan bahwa kondisi Pelabuhan Tanjung Samak berkaitan dengan pelayanan dan fasilitas penumpang belum terorganisasi dengan baik, mengingat bahwa masih banyak fasilitas yang belum ada dan belum tersedia sesuai kebutuhan masyarakat atau penumpang. Semakin pelayanan dan fasilitas Baik, maka akan semakin tinggi juga nilai kepuasan masyarakat atau penumpang terhadap Pelayanan dan Fasilitas penumpang Terminal Pelabuhan Tanjung Samak yang dilihat dari 4 indikator yaitu fasilitas umum (29\%) dinyatakan Cukup, fasilitas terminal penumpang (35\%) dinyatakan Cukup, fasilitas operasional penumpang $(20 \%)$ dinyatakan Cukup dan fasilitas penunjang $50 \%$ dinyatakan Sedang. Hal ini didukung oelh teori Bambang Triatmodjo (2009) yang menjelaskan bahwa Prasarana dan Sarana Pelabuhan pelabuhan untuk dapat menjalankan 
fungsinya, harus memiliki 2 pelayanan yaitu Pelayanan Kapal dan Pelayanan Penumpang \& Barang. Dalam hal ini yang termasuk dalam Pelayanan Kapal meliputi; Alur masuk pelabuhan dan sistem sarana bantu navigasi pelayaran, kolam pelabuhan, pemecah gelombang, dermaga dan kapal tunda, kapal pandu, kapal kepil, dan sebagainya. sedangkan yang termasuk dalam pelayanan penumpang dan barang, meliputi: apron dermaga, gudang, gedung terminal penumpang, lapangan parkir, areal bongkar muat moda angkutan darat, akses ke sistem pengangkutan darat, sarana debarkasi dan embarkasi penumpang, dan alat bongkar muat, seperti kran, derek, forklift, dan sebagainya.

Menurut Triatmodjo (2009), untuk bisa memberikan pelayanan yang baik dan cepat, maka pelabuhan harus bisa memenuhi beberapa persyaratan, yaitu; harus ada hubungan yang mudah antara transportasi laut dan darat seperti jalan raya, sedemikian sehingga barang-barang dapat di angkat ke dan dari pelabuhan dengan mudah dan cepat. Pelabuhan berada di suatu lokasi yang mempunyai daerah belakang (daerah pengaruh) subur dengan populasi penduduk yang cukup padat. Pelabuhan harus mempunyai kedalaman air dan lebar yang cukup. Kapal-kapal yang mencapai pelabuhan harus bisa membuang sauh selama menunggu untuk merapat ke dermaga guna bongkar muat barang atau mengisi bahan bakar. Dan Pelabuhan harus mempunyai fasilitas untuk mereparasi kapal.

KESIMPULAN
Berdasarkan hasil penelitian dan
pengamatan tentang Pelayanan dan
Fasilitas penumpang Terminal Pelabuhan
Tanjung Samak, maka dapat disimpulkan
bahwa:

1. Pelayanan dan Fasilitas penumpang Terminal Pelabuhan Tanjung Samak memiliki nilai indeks (29\%) dinyatakan Cukup untuk indikator Fasilitas Umum. Hal ini dapat dilihat bahwa fasilitas yang menghubungkan dengan operasional kapal, seperti ponton dan alat penambat masih dalam perbaikan dikarenakan ponton mengalami kerusakan daikibatkan cuaca buruk sehingga menganggu kenyamanan penumpang dalam melakukan keberangkatan. Selain itu, fasilitas yang menghubungkan dengan perpindahan penumpang, seperti jembatan dan selasar penghubung. Juga dalam keadaan kurang baik yaitu berupa papan kecil untuk melintas dari kapal ke pelabuhan sehingga membahayakan penumpang.

2. Pelayanan dan Fasilitas penumpang Terminal Pelabuhan Tanjung Samak dengan nilai indeks 35\% dinyatakan Cukup untuk indikator Fasilitas Terminal Penumpang. Hal ini dapat dilihat bahwa Pelayanan pra dan purna perjalanan penumpang belum ada. Pelayanan informasi dan penjualan tiket sudah ada tapi belum memiliki agen tiket yang menetap pada pelabuhan. Pelayanan proses perpindahan penumpang dan barang kurang memadai dikarenakan belum memiliki tempat penampung barang bawaan penumpang. Pelayanan penunjang untuk memenuhi kebutuhan penumpang belum memadai tapi sudah bisa digunakan untuk lancarnya aktivitas kepelabuhanan. Dan Pelayanan pengawasan penumpang sudah ada di tangani oleh Dinas Perhubungan, Syahbandar dan Polisi Pelabuhan.

3. Pelayanan dan Fasilitas penumpang Terminal Pelabuhan Tanjung Samak dengan nilai indeks $20 \%$ dinyatakan Cukup untuk indikator Fasilitas Operasional Penumpang. Hal ini dapat dilihat bahwa fasilitas pada parkir belum terkoordinasi dengan baik dimana penumpang dan pengantar meletakkan kendaraannya dan menurunkan penumoang pada badan jalan sehingga kurang tertib. Pelantar naik turunnya penumpang masih berupa papan penyeberangan kecil sehingga membahayakan penumpang. Fasilitas pejalan kaki belum tertib karena masih bercampur dengan jenis kendaraan. Dan fasilitas jalan masuk kendaraan sudah ada. 
4. Pelayanan dan Fasilitas penumpang Terminal Pelabuhan Tanjung Samak dengan indeks 50\% dinyatakan Sedang untuk indikator Fasilitas Penunjang. Hal ini dapat dilihat bahwa Fasilitas Penunjang yang tersedia yaitu fasilitas komersial dan fasilitas perkantoran. Fasilitas komersial berupa rumah makan sudah tersedia tapi masih bangunan baru yang terdapat dipinggir pelabuhan dan warung kecil, dan untuk fasilitas Kantor terdapat 2 Kantor Dishub dan Kantor Syahbandar yang melakukan pengawasan pada pelabuhan.

5. Berdasarkan Pelayanan dan Fasilitas penumpang Terminal Pelabuhan Tanjung Samak dapat dikatakan belum sesuai standar, hal ini berdasarkan fasilitas yang tersedia dan pelayanan penumpang pengguna jasa yang tidak sesuai dengan standar berdasarkan Peraturan Menteri No. 37 Tahun 2015, dimana masih terdapat fasilitas yang tidak ada dan kurang memadai dengan kondisi jumlah penumpang dan kondisi fisik pelabuhan yang mengalami kerusakan.

\section{DAFTAR PUSTAKA}

Arikunto, S..2009. Evalusi Program Pendidikan. PT. Bumi Askara: Jakarta

Arikunto,S.2010. Prosedur Penelitian :suatu Pendekatan Praktek. Gramedia: Jakarta

Ayuriyanti dan S, Dwi. 2015. Hambatan guru dalam perencanaan, pelaksanaan dan penilaian pembelajaran kompetensi keahlian multimedia pada penerapan kurikulum 2013 di smk se daerah istimewa Yogyakarta (Skripsi). Universitas Negeri Yogyakata :Yogyakarta

Devi Amelia Ayuningtias, Ratna Purwaningsih. 2015. Penilaian Standar Kelayakan Pelayanan Penumpang Pelabuhan Tanjung Emas semarang.

Hardianti dan Sitti. 2017. Implementasi kurikulum 2013 Pada Proses Pembelajaran Oleh Guru Mata
Pelajaran Fisika Tingkat SMAN di Kabupaten Bone. (Skripsi). Uin Alaudin: Makasar

Morlok, Edward K 2005. Teknik Pengakutan, Teknik Transportasi, Erlangga: Jakarta

Nazir, Moh. 2005. Metode Penelitian. Ghalia Indonesia: Jakarta

Pius Honggo Wijoyo. 2012. Terminal Penumpang Kapal Luat Pelabuhan Harbour Bay Pulau Batam. (Skripsi). Fakultas Teknik. Universitas Atma Jaya Yogya Karta.

Peraturan Mentri Nomor 37 Tahun 2015 Standar Pelayanan Penumpang Angkutan Laut.

Rahmat Hidayat. 2016. "Kualitas Pelayanan Jasa Terminal Penumpang Pada Pelabuhan PT.PELINDO I (PERSERO) Sri Bayitan Kijang". Program Studi Ilmu Administrasi Negara, Fakultas IImu Sosial dan Ilmu Politik, Universitas Maritim Raja Ali Haji.

Samsul Fikri. 2017. Analisis Pemuatan Dokumen Pemuatan Terhadap Kepuasan Pelanggan Di PT. Vinici Inti Lines Cabang Tanjung Balai Karimun. (Skripsi). Fakultas Perikanan Dan Ilmu Kelautan. Univeristas Karimun: Karimun

Sugiyono. 2013. Metode Penelitian Kuantitatif, kualiitatif dan $R \& D$. AlfaBeta: Bandung

Sugiyono. 2014. Metode Penelitian Kuantitatif, kualiitatif dan $R \& D$. AlfaBeta: Bandung

Triatmodjo.B. 2009. Perencanaan Pelabuhan. Beta Offset. Yogyakarta

Undang-Undang Nomor 17 Tahun 2008 Tentang Pelayaran, Sinar Grafika: Jakarta

Yulianto, Nur Achmad Budi, Mohammad Maskan, Alifulathin Utanminingsih. 2018. Metodoogi Penelitian Bisnis : Polenema Press, Politeknik Negri Malang : Malang.

Widi dan R, Kartiko. 2018. Menggelorakan Penelitian; Pengenalan dan penuntun Pelaksanaan Penelitian. CV Budi Utama: Yogyakarta. 